\title{
Earning the Keys to the Kingdom: Students' Language Awareness, Identity and Representations of English-Speaking Others
}

\author{
Carmen Lucas ${ }^{1,2}$ \\ ${ }^{1}$ Departamento de Letras, Artes e Comunicação, Universidade de Trás-os-Montes e Alto Douro \\ ${ }^{2}$ Escola Superior de Educação, Instituto Politécnico de Bragança \\ Correspondence: Carmen Lucas, Departamento de Letras, Artes e Comunicação, Universidade de Trás-os-Montes \\ e Alto Douro, Edifício do Pólo I da ECHS, Quinta de Prados, 5000-801 Vila Real, Portugal. Tel: 351-936-861- \\ 771. E-mail: carmenlucas3@gmail.com
}

Received: July 14, 2021; Accepted: July 24, 2021; Published: July 26, 2021

The research is not financed.

\begin{abstract}
The present linguistic reality involves finding ways of communication in the globalized environment, where people move all around the world in order to find work, learn, or share experiences. One issue arising from English language teaching is that it has mainly overlooked teaching culture across the curriculum, thus allowing the increase of negative attitudes and stereotypes.

This paper is set out to determine to what extent English language teaching (ELT) materials demonstrate the traits of the English-speaking Other, it what ways children are accessing the target 'Kingdom', and which are the best teaching strategies to provide them with the keys to the target world. Anchoring our perspective in CLIL and the $4 \mathrm{Cs}$, this study looks at ways of developing cutting-edge syllabi to develop intercultural awareness and preventing stereotypes. Findings from the application of the syllabi and resulting from an analysis of the cultural content of two internationally distributed ELT textbooks are reported. The present research put in evidence that cultural aspects are practically absent from the analyzed textbooks, thus lacking a key dimension in English Language Teaching and Education. Therefore, some recommendations for future textbook writers and EFL classroom practice are suggested.
\end{abstract}

Keywords: English Language Teaching, Young Learners, Textbooks, CLIL, Intercultural Awareness, Textbooks, Syllabi Design

\section{Introduction}

\subsection{Introducing the Problem}

English language has acquired the status of an intercultural language, added to its hegemony (Bessie, Dendrinos and Gounari, 2006). This is reflected in the amount of taught English language programmes to Young Learners across the world, under the form of foreign or second language. Learning a language should provide young learners with the "keys to the kingdom", this is access to other social cultural worlds as well as a clearer understanding of their own. However, scarce research has looked at what worlds are being accessed and what is being learnt there. Considering that the "target world", the "Kingdom" is structured and mediated through syllabi, course books and texts, it can be stated that the target worlds the learners encounter are not reflections of "real worlds", but representations formed accordingly to multiple cognitive and social belief systems, informed by the structuring stereotypes. Stereotypes, are by definition, in line with the Oxford English Dictionary a "widely held but fixed and oversimplified image or idea of a particular type of person or thing". Within foreign language learning spreading throughout the world, and the issue of English being a hegemonic language, associated to the people's cultural identity, which is in our own view of primary importance, as is the expediency of the target variety in communicative terms. Therefore, English Language Teaching (ELT), in order to be an agent in the promotion of linguistic human rights, needs not only a lingua-franca vision of standard English but also a cultural studies platform which promote the development of non-native speaker identities (Canagarajah, 2003; Modiano, 2005; Rajagopalan, 2005). It should therefore be taught within an intercultural view. Further we should here highlight 
the previously mentioned question of "what worlds are being accessed implicitly through the foreign language/syllabus/materials provided to primary school children?

The existing available studies report that when primary school children were questioned about the purpose of learning a foreign language (English), they often mentioned utilitarian reasons, connected with the need of travelling and communicating with the speakers of the target language (Nikolov, 1999; Barbosa, 2004). In turn this suggests that an intercultural awareness was built within the learners, establishing a positive bond among their own identity (the self) and the foreign language identity, with an underlying view of fostering Intercultural Communicative Competence (ICC) simultaneously. These findings resonate the L2 self-construct proposed by Dörnyei (2005), which was positively embedded in children's personalities. This awareness of the 'Foreign Language Speaking Other' is key in terms of preventing stereotypes in relation to other languages and cultures (Byram, 1997). In today's global world it is important that children are entitled to efficient foreign languageteaching from a very early age. Within EFL reading instruction, enhancing children's Intercultural Communicative Competence might be fostered through cartoon-like materials containing contrastive analysis: for example, if children are learning about an English breakfast, which is different from a daily Portuguese one, intercultural awareness arises; children do question why and accept very naturally that peoples from different cultures have different eating habits (Arikan \& Taraf, 2010). For example, a typical Portuguese breakfast includes milk and bread with cheese or butter, whereas a typical British breakfast is more likely to include bacon, sausages, eggs and beans (Figure 1).

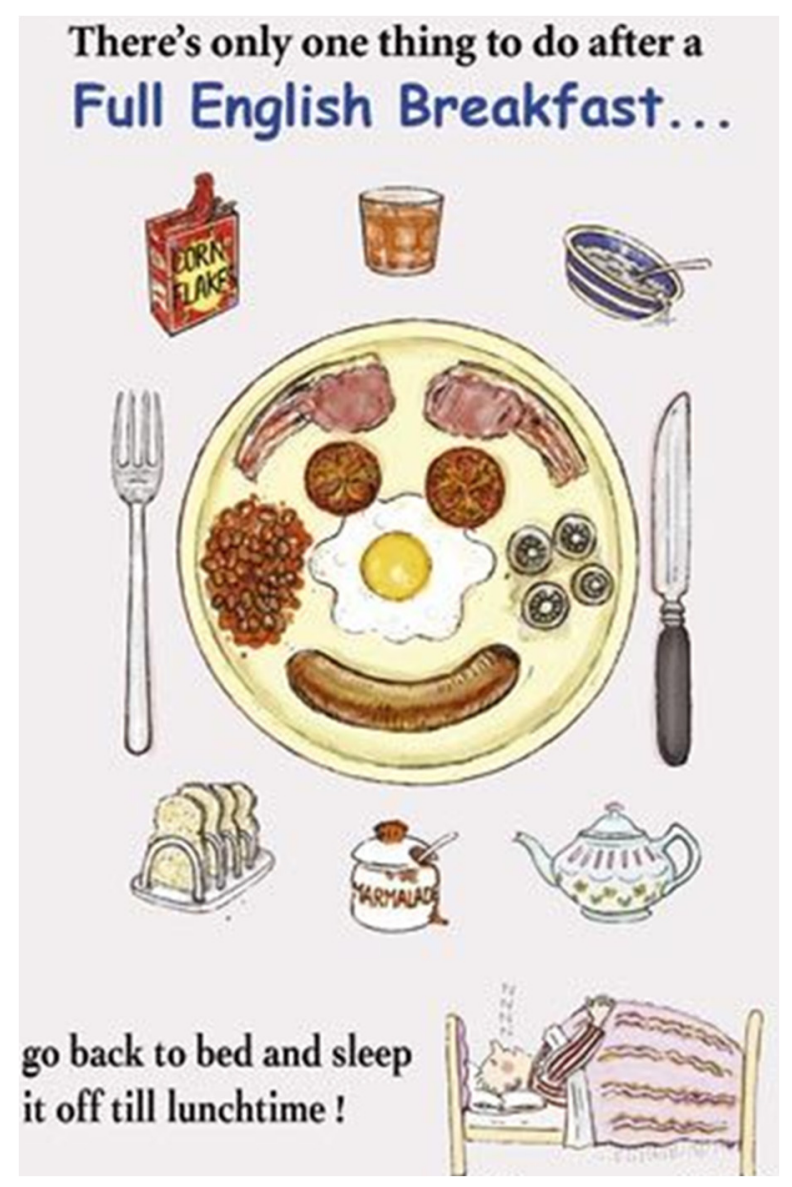

Figure 1. Illustrative figure, depicting a traditional, full English breakfast

These cultural differences are those which children more easily recall and might certainly be the key to the Kingdom, as they provide a window of opportunity for children to access the target Culture. Alternatively, an authentic storybook might be another way of providing children access to foreign-speaking worlds (i.e. vocabulary and grammar), as the language embedded is the target language and strengthening their Intercultural Communicative Competence. Therefore, to teach children these cultural contrasts in their early primary school years is to create within them naturalness in accepting different cultures where different languages are spoken 
while preserving their own identities. This is in line with the view proposed by Byram (1997), is that education should focus more on intercultural aspects so that learners can develop "awareness, attitudes, skills, and knowledge that will make [them] better participants on a local and global level, able to understand and to empathize with others in new ways" Furthermore, he points out that the development of IC is an on-going and lifelong process in as much as one is always in the process of 'becoming' and is never completely interculturally competent. He emphasizes that although one may develop and expand one's competencies, new challenges always appear, and a good condition for one to develop one's IC is the contact and experience with people of other languages and cultures in a positive setting. In agreement with this theoretical framework, the positive setting of the current study was the EFL classroom, since through the use of authentic storybooks, narrated in English and materials featuring English characters, is providing children with a window for intercultural communication, as providing them access to a different social setting.

Added to the studies conducted by Gardner and his colleagues, the research carried out by Nikolov (1999) is of significance. In her research with young learners the author presented a longitudinal study entitled Why do you learn English? Because the teacher is short. The findings point to the long-term positive effects of specific pedagogic procedures. Participants were followed over an eight-year length through a Government Project in Hungary, between the ages of 6 and 14, where the teacher, syllabus designer and researcher were the same for that period. Among the main conclusions, children aged 6-7 years old gave as main reasons to learn English classroom related reasons, teacher related reasons, family related, external and utilitarian reasons. In addition, the younger learners associated English learning to their enjoyment in sharing their learning with their families (even trying to teach them), which actually is an emergent finding from the present study through lesson transcription, informal talks with parents, educators and observation in playground.

The study with Hungarian children learning English demonstrated that even with the increase of age, learners who have had an early start, around puberty, where learners tend to become more critical, English was still being listed as one of their favourite school subjects. In sharing their foreign language learning, taking their experiences from the foreign language classroom into the privacy of their homes, children were indeed establishing intercultural communication through the foreign language.

Another reported effect was that when learners were asked why they thought they were learning English, they replied 'because I am teaching my mother/sister/brother or because my brother/sister/cousin also learns English'.

Further, one of the key reasons pointed by learners was related to the classroom environment, specific pedagogic procedures. Most children signaled within the lessons the value of language play through expressions such as 'because we just play', 'because it is so good [fun], 'we only play and listen to stories. In turn, creative foreign language use, nursery rhymes, storybooks, general language games have been related to successful foreign language learning (Crystal, 1998; Cook, 2000). A phenomenon happening in many countries is that when learners reach their teenage years, they start to dislike their learning in foreign languages, increasing their resistance in learning it (Pemberton, 2008). At the same time, they start resisting the culture that comes along the language as well as its people. "Stereotypes are tenacious and do not disappear simply as a consequence of exposure to attractive images in the process of language learning" (Moreira, 2004; Talero, 2004). Therefore, ICC becomes more difficult to develop within students' own identities. As such, starting to learn foreign languages in early primary school years might present the advantage of since an early age children becoming aware that they are not alone in their small country and that across the world many other languages are spoken thus accepting the foreignlanguage speaker 'Other? As naturally as possible and counteracting prejudice. Therefore, as Coyle argues:

"But I do think that the sooner the children understand that words are only representations of the world and that they aren't a fixed entertain, the better it is. And I think the children who have bilingual experiences understand that much sooner than monolingual children. Therefore, I think there's a kind of entitlement for monolingual children as well to have this understanding about what words are and how they operate in different languages and what communication means" (Coyle, 2008).

Besides diminishing children's egocentric view of the world, EFL learning raises awareness that learning languages is necessary, as well as raising Intercultural Communication Competence, thus preventing stereotypes. In the context of the UK (England), an education policy announced in Spring 2007, was aimed at the introduction of learning primary modern and foreign languages (PMFL) to all children from the age of 8 by the year 2010 (Woodgate-Jones, 2009). This political action was understood as having the potential of fostering ICC, preventing negative attitudes, as supported by a primary modern and foreign language teacher (PMFL), teaching French in the UK:

(PMFL Learner): "well, why do we have to learn another language if everybody in the world speaks English?” 
In an attempt to encourage coherence, and support teachers in promoting a more structured and consistent approach towards the key aspects of FL learning, the Curriculum Orientations for Teaching English in Primary Schools was produced and trialed during 2007-2008. It provided EFL teachers in Portuguese primary state schools to have a single framework to work from. In addition, it provided an approach to teaching EFL, comprising three progressive strands of oracy, foreign language literacy and intercultural understanding, with two crosscutting strands: knowledge about language and language learning strategies. However, this framework is not statutory and despite the aims stated in official documentation, it is the teachers themselves who will be interpreting the EFL curriculum and therefore implement the approach considered most appropriate. Although learning foreign languages such as English is available across a wide range of national contexts, little is known about the attitudes of primary children towards EFL or indeed about the effects of the introduction of a foreign language in the primary school curriculum. Furthermore, traditional language teaching, specifically related to the learning outcomes verified in children who have been learning English as a foreign language in primary state classrooms, has been criticized for providing them with neither the necessary skills nor the courage to communicate with speakers of other languages. One way of achieving this purpose is by designing syllabi which incorporate principles from CLIL and the 4 Cs (Figure 2).

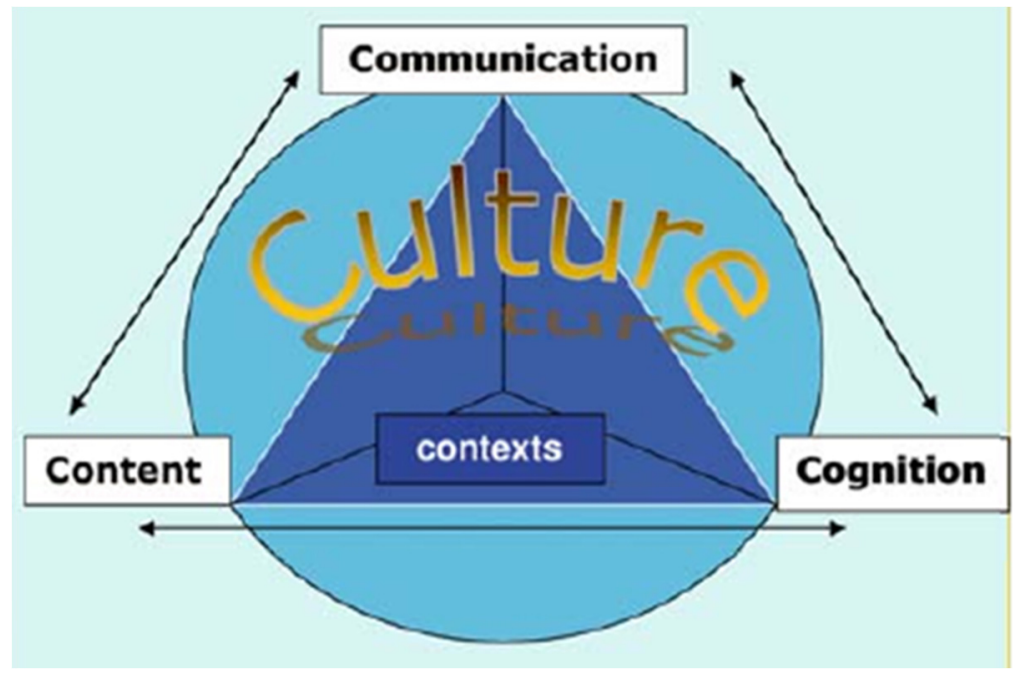

Figure 2. The Four Cs Framework (Coyle, 2019)

Working towards a cohesive conceptual tool, and influenced by the early work of Mohan and his Knowledge Framework (1986), Coyle (1999; 2020) developed the 4Cs Framework (Figure 1). This Framework is cutting-edge regarding world languages education strategy Standards for Foreign Language Learning in the 21st Century. Although some interesting links can be made (e.g., communication, cultures and connections), there is a difference in emphasis since the starting point is language education. The 4Cs framework for CLIL starts with content (such as subject matter, themes, cross-curricular approaches) and focuses on the interrelationship between content (subject matter), communication (language), cognition (thinking) and culture (awareness of self and 'otherness') to build on the synergies of integrating learning (content and cognition) and language learning (communication and cultures). It unites learning theories, language learning theories and intercultural understanding. According to Coyle (2020), the 4Cs Framework holds that it is through progression in knowledge, skills and understanding of the subject matter, engagement in associated cognitive processing, interaction in a communicative context, developing appropriate language knowledge and skills as well as acquiring a deepening intercultural awareness through the positioning of self and 'otherness', that effective CLIL takes place whatever the model. From this perspective, CLIL involves learning to use language appropriately whilst using language to learn effectively. The 4 Cs Framework is a tool for any level and any age.

The present study also intends to be a contribute to previously published research by Mourão \& Lourenço (2015), bearing in mind that the age for early language learning has dropped dramatically in the past decade to include children under 6 years old, whereas very little published research exists regarding children's attitudes and their views of the target Culture and English-speaking others. It is therefore timely appropriate to explore the effects of the introduction of EFL in Portuguese primary curriculum and if the appropriate conditions are being provided to foster children's positive attitudes and overall foreign language literacy development. 
As such the main research question for the present study is "to what extent EFL syllabi and programmes provide access to the target culture and to language of the "Kingdom?"

\subsection{Importance of the Problem}

In spite of the overall support for the use of children's literature and language play as methodological teaching strategies, research is needed to address which pedagogical methods are being used to provide children's access to the target culture and how are stereotypes being prevented, thus enhancing intercultural awareness.

Traditional methods which attribute the teacher a central role and the learners a passive role and present an explicit and de-contextualized language instruction which is not appropriate for the characteristics and needs of young learners and teachers are not satisfied with the results obtained through traditional methods (Nunan, 1999). This view is supported by the research regarding young learners' English language classrooms in Portuguese state primary classrooms, where methods, strategies and materials have been considered to be rather inadequate (APPI/National Portuguese Ministry of Education report 2006-2007; 2007/2008; Mourão \& Lourenço). Further these reports also echo that most EFL language teachers do not appeal to young learners' characteristics and thus cannot cater for the need to contextualize EFL language instruction. Drawing on the identified issues related to teaching English to young learners it is believed that new insights should be incorporated into teaching YLs.

The study was carried out between October 2017 and June 2018.

\subsection{Hypotheses and Research Design}

The research focused mainly on two of the key aspects identified in the document Orientations for primary English Teaching (DGIDC, 2006): 'English language competence' and 'pluricultural, plurilingual awareness', but aspects such as foreign language reading motivation were also considered. The main hypothesis was that if children are entitled to pedagogic materials that raise awareness of other languages and cultures, this will potentially dimmish their stereotypes and resistance to learn other languages, namely the English language. The present research was targeted at obtaining a deeper understanding how primary school children perceive English-speaking others and the target culture.

\section{Research Design}

\subsection{Instruments}

\section{a) The attitude questionnaire}

A special instrument developed in 1999 by Marianne Nikolov applied to Hungarian EFL learners was adapted and applied in January 2019 to Portuguese primary EFL learners in the process of exposure to foreign language learning (English) in order to assess attitudes in general, the learning situation and motivation. This was a questionnaire, which consisted of six open questions in Portuguese and was administered in the beginning of the second term of the academic year. It was presented in English and in the children's native language (Portuguese), to ensure the participant researcher obtained reliable answers.

\section{b) The plurilingual school play}

Throughout the academic year the EFL teacher in cooperation with the primary school teacher prepared a multilingual school play, which included three languages - English, Portuguese and French, as some of the learners had immigrant parents working in France (Appendix 1). It was carried out in an open space, where children's parents could attend to it, and this initially 'de-motivated' group was able of putting in use the foreign language they had been learning and other they had had even more limited contact with.

Regarding instructional material, a set of storybooks were used, such as "The Very Hungry Caterpillar", "A Squash and a Squeze", "We're Going on a Bear Hunt", followed by story retelling as the teacher turned the pages. This strategy prompted classroom lovely interaction and counteracted children's reluctance in using English in the classroom. Further, sequencing story activities as well as reading and writing worksheets were provided to verify children's second language learning regarding reading and writing.

\subsection{Participants Characteristics}

This study was carried out in a primary school classroom, encompassing the four grades of primary education (all place and participant names are pseudonyms), which was located in a rural area in the northeast Portugal, classified as a low-SES setting. The pupils were predominantly from economically challenged backgrounds, bearing in mind that about $40 \%$ qualified for free and reduced-price lunches during the school year and entitlement to a social worker. The school did not have any technological equipment, so the participant researcher needed to take all the necessary materials in advance. The school followed the national curriculum framework that the participant 
researcher directly aligned with the action-research plan to target key curriculum themes, such as social studies, mathematics and arts and crafts. The class' daily schedule started with individual literacy and mathematics activities as morning work, before the regular daily classes in content areas including English as a second language as the last taught subject.

\subsection{Sites and Participants}

The school in the present study was considered as a high-poverty, low-performing school according to state Department of primary state instruction and primary teacher reports. The sample for this study included first, second, third and fourth grade primary school children $(n=80)(6-9$ years old $)$, from a low-SES setting, attending EFL primary sessions in two Portuguese state schools. Research ethics were adhered to by following the British Education Research Association (BERA) that endorses the set of ethical principles agreed in 2015 by the Academy of Social Sciences (AcSS) through in-depth consultation with its member learned societies, including BERA: Ethical Guidelines for Educational Research, fourth edition (2018).

\section{Results}

In order to obtain an in-depth understanding of our research questions, besides the storybooks used and other tailored designed pedagogic materials, there was also resort to analyses of two textbooks in use to understand to what extent they convey the cultural elements necessary to expand children's view of the target Culture and ultimately the view of an intercultural world.

In face of English language teaching programmes in primary school widespread, these developments call for a close look into the content which informs language education (Byram \& Carol, 1994; Kramsch, 2004; Coyle 2010; Coyle, 2020). However, little attention is generally given to what worlds, what target culture is being accessed implicitly through the Foreign Language children are learning. A phenomenon happening in many countries is that when learners reach their teenage years, they start to dislike their learning in foreign languages, increasing their resistance in learning it (Pemberton, 2008). At the same time, they start resisting the culture that comes along the language as well as its people. "Stereotypes are tenacious and do not disappear simply as a consequence of exposure to attractive images in the process of language learning" (Moreira, 2004; Talero, 2004). Therefore, Intercultural Communicative Competence becomes more difficult to develop within students' own identities. As such, starting to learn foreign languages in early primary school years might present the advantage of since at an early age children becoming aware that they are not alone in their small country and that across the world many other languages are spoken thus accepting the foreign-language speaker 'Other' as naturally as possible and counteracting prejudice, thus providing them with "the keys to the Kingdom".

Conversely, not all English language Teachers in the Portuguese context and other similar contexts are well aware of intercultural language teaching and of CLIL 4Cs since there is a lack of instructional design models to integrate intercultural content into English language classes, namely during reading instruction (Tran and Duong, 2018). National policies seem to be far from the cutting-edge 4Cs view. Although The Portuguese General Board of Innovation and Curricular Management (DGIDC) has been clear in its vision of promoting both language competence and intercultural understanding: 'English language learning as an instrument for international communication and its key role in building a plurilingual and pluricultural awareness, in line with the Common European Framework of Reference for Languages (2001)', most English Language Teachers dismiss this dimension in their teaching, thus giving rise to negative attitudes and stereotypes.

As the matter of fact, in an attempt to encourage coherence, and support English Language teachers in promoting a more structured and consistent approach towards the key aspects of FL learning, the Curriculum Orientations for Teaching English in Primary Schools was produced and trialed during 2007-2008. It provided EFL teachers in Portuguese primary state schools to have a single framework to work from. In addition, it provides a systematic approach to teaching EFL, comprising three progressive strands of oracy, foreign language literacy and intercultural understanding, with two crosscutting strands: knowledge about language and language learning strategies. However, this framework is not statutory and despite the aims stated in official documentation, it is the teachers themselves who will be interpreting the EFL curriculum and therefore implement the approach considered most appropriate. As a consequence, this linguistic educational reform has prompted the need to revise foreign language education curriculum, searching the best ELT methodologies to enhance young learners' positive attitudes and foreign language reading development. Because of the unique communicative opportunities offered by English and its dominance in global communication, technology, science and research, the central place of English in the primary school curriculum has become guaranteed (Henry \& Apelgreen, 2008; Mourão \& Lourenço, 2015). 
The Portuguese General Board of Innovation and Curricular Management (DGIDC) is however clear in its vision of promoting both language competence and intercultural understanding: 'English language learning as an instrument for international communication and its key role in building a plurilingual and pluricultural awareness, in line with the Common European Framework of Reference for Languages (2001)'. In an attempt to encourage coherence, and support teachers in promoting a more structured and consistent approach towards the key aspects of FL learning, the Curriculum Orientations for Teaching English in Primary Schools was produced and trialled during 2007-2008. It provided EFL teachers in Portuguese primary state schools to have a single framework to work from. In addition, it provides a systematic approach to teaching EFL, comprising three progressive strands of oracy, foreign language literacy and intercultural understanding, with two crosscutting strands: knowledge about language and language learning strategies. However, this framework is not statutory and despite the aims stated in official documentation, it is the teachers themselves who will be interpreting the EFL curriculum and therefore implement the approach considered most appropriate. As a consequence, this linguistic educational reform has prompted the need to revise foreign language education curriculum, searching the best ELT methodologies to enhance young learners' positive attitudes and foreign language reading development. Because of the unique communicative opportunities offered by English and its dominance in global communication, technology, science and research, the central place of English in the primary school curriculum has become guaranteed (Henry \& Apelgreen, 2008; Mourão \& Lourenço, 2015). Besides the present author and participant researcher, four semistructured interviews were carried out in order to triangulate the preliminary findings (Richards, 2003; Dörnyei, 2005). Interviews took place at expertise's office within the field of foreign and second language pedagogy, based the University of Nottingham's School of Education and at University of Nottingham's School of English Studies, United Kingdom. Protocols for semi-structured interviews were designed prior to interviews and followed the research interview guidelines from Lanza (2004). In order to ensure research ethics consent forms were prepared and signed by interviewees.

\subsection{Data from Questionnaire Application \\ a) Reasons for Learning English}

As already stated in the instruments' section, within the study a questionnaire priory developed by Nikolov (1999) was applied into the EFL classroom. The first question inquired children about the reason they are learning a FL English. Children's answers can be grouped into 4 broad types: a) willingness to communicate; b) the classroom experience; c) external reasons and d) utilitarian/instrumental reasons.

The youngest primary learners (6-7-year-olds). The participating children in the first two grades of primary school provided the following reasons: willingness to communicate related-reasons: 'talk in English'; 'to know more about the language'; 'It's good to learn the language'. External, utilitarian reasons were represented by statements such as: 'to travel to other countries'. All the answers provided by this group were positive statements. Children also listed English as a favourite school subject (9/10), although it is not a compulsory school subject in primary school curriculum.

When providing these reasons children tend to look ahead into the future and they typically mention either very general points or specific situations where the knowledge of English will be useful. Moreover, this is in line with recent trends from second language acquisition research related to willingness to learn the target language and children's willingness to communicate with foreign-speaking others (Tannenbaum \& Tahar, 2008; MacIntyre, Baker, Clément \& Donovan, 2002, 2003; Dörnyei, 2003, 2005). It might be further argued that children are picturing themselves as proficient L2 speakers, thus providing a basis to argue both instrumental and integrative motivation.

A difference has emerged however in relation to the younger group, external, negative- like reasons such as: 'it is compulsory' (4); 'I don't understand a thing about English'(3) and 'I don't like English' (9).

A general tendency can be isolated from children's answers, linked to utilitarian reasons. In relation to the registered negative answers/attitudes, the reason for this phenomenon must be due to negative experiences in other school subjects, as reported by the primary school teacher. As children were accustomed to low achievements in their native language, their expectations for success in the target language as well as their self- esteem levels were very low. As these attitudes also reflect a negative attitude towards the learning context, activities and tasks, and a lack of an intrinsic motive, an action-plan was drawn and implemented into the classroom, resorting to authentic storybooks. It should be mentioned that although the questionnaire was not administered a second time, audiorecordings of EFL sessions allowed to depict a progress in children's attitudes, which also reflected in the classroom's group dynamics and less occurrence of disruptive behaviours. This attitudinal change culminated in a 
school play performance, where these apparently 'de-motivated' learners were able to present a school play in English, Portuguese and French.

The emergence of willingness to communicate with foreign-speaking others Integrative motives emerged from children's answers (i.e. reference to native speakers), thus revealing a strong desire to make themselves understandable to foreign- language speaking others. Although learners did not identify it specifically, it is implicit in children's answers the status of English as the means of international communication: 'because my mother said that if I am going to travel it is very necessary'; 'if I go anywhere in the country [England] with English people understand me and I understand them'.

It might be further argued that traditional testing might be one of the causes of children's negative attitudes as they identify 'tests' as a threat. Our own interpretation of children's attitudes is that they might have previously worked in a pedagogical school context where, unlike in English sessions, mistakes were always perceived as signs of deficiencies rather than signs of development. Further initially their primary teacher attitude towards the FL was not encouraging. As registered in researcher's field notes, she requested the EFL teacher: 'could you teach English in Portuguese? These are cognitively very limited children'.

\section{b) The Status of English among other School Subjects}

The second and third questions aimed at finding out the place of English in primary school curriculum among other school subjects from the learners' perspective. There appears to be an overall enthusiasm, 'involvement' in 1st and 2nd grades of primary school. In a sample of 10, 9/10 children (age 6-7) listed English as their favourite school subject whereas in 3rd and 4thgrades (age 8-9), in 13 returned questionnaires, only 5 children listed English as their favourite school subject. This is in line with our previous argument that children's enthusiasm to learn foreign languages and accept the 'other' changes/declines with age.

\section{c) Mother Tongue and other Foreign Languages}

In the purposive sampling stage (2019), one unexpected finding was that children reflected a negative attitude towards their own ability to mother tongue learning in general, but specifically to learning English. Some children would say 'I'm like a donkey, I cannot learn, you can ask our primary teacher'. Although mother-tongue development is not within the range of this study, it has been found that L1 cognitive/academic language proficiency predicts success in foreign language learning (Skehan, 1989). Therefore, negative attitudes towards the mother tongue as a school subject might influence foreign language study in undesirable ways.

\section{Discussion}

The present study brought to light several issues concerning English Language Teaching in Portuguese primary schools. From the collected data (questionnaire, plurilingual school play, syllabi design containing elements of the target culture, research interviews), it is possible to state that intercultural communication activities can be advocated as an accompaniment to more traditional methods of promoting behavioural and attitudinal change which is often focused upon uni-directional teacher instruction and guidance, or in other words - being told what to think by a teacher. This may be especially true when learners are engaged in intercultural learning activities designed to identify and challenge stereotypes, prejudices and foster the development of positive attitudes toward foreign language groups.

Further and as mentioned in the materials' section, at the end of the academic year children were challenged to perform a plurilingual school play, which clearly puts in evidence the role of the teacher as a 'coacher', thus enhancing EFL learner's active response. As some of the children's parents were immigrated in France, they would use French, Portuguese and English. Therefore, we believe this was a strong opportunity to foster foreign languages' literacy development among primary school children. In resorting to a plurilingual school play which included languages with which their families had contact to, links among those cultures and children's own identities were created, thus providing children with "the keys for the Kingdom".

\section{References}

Arikan, A., \& Taraf, H. (2010). Contextualizing young learners' English lessons with cartoons: Focus on grammar $\begin{array}{lllr}\text { and vocabulary. Procedia Social Behavioural Sciences 2, 5212-5215. } & \text {. }\end{array}$ https://doi.org/10.1016/j.sbspro.2010.03.848

Ben-Rafael, E., \& Brosh, H. (1991). A sociological study of second language diffusion: the obstacles to Arabic teaching in the Israeli school. Language Problems and Language Planning, 15, 1-23. https://doi.org/10.1075/lplp.15.1.01ben

Byram M., \& Carol M. (1994). Teaching-and-learning-Language-and-Culture. United Kingdom: Multilingual 
matters. ISBN-13: 978-1853592119

Byram, M. (2002). Foreign language education as political and moral education - an essay. Language Learning Journal, 26(1), 43-47. https://doi.org/10.1080/09571730285200221

Byram, M., \& Feng, A. (2005). Culture and language learning: teaching, research and scholarship. Language Teaching, 37, 149-168. https://doi.org/10.1017/S0261444804002289

Catts, H. W., Fey, M. E., Zhang, X., \& Tomblin, J. B. (2001). Estimating the risk of future reading difficulties in kindergarten children: A research based model and its clinical implementation. Language, Speech and Hearing Services in School, 32, 38-50. https://doi.org/10.1044/0161-1461(2001/004)

Chaney, C. (1998). Preschool language and metalinguistic skills are links to reading success. Applied Psycholinguistics, 19, 433-446. https://doi.org/10.1017/S0142716400010250

Clements, M. A., Reynolds, A. J., \& Hickey, E. (2004). Site-level predictors of children's school and social competence in the Chicago Child-Parent Centers. Early Childhood Research Quarterly, 19, 273-296. https://doi.org/10.1016/j.ecresq.2004.04.005

De-Abreu, M. D., \& Cardoso-Martins, C. (1998). Alphabetic access route in beginning reading acquisition in Portuguese: The role of letter-name knowledge. Reading and Writing: An Interdisciplinary Journal, 10, 85104. https://doi.org/10.1023/A:1007939610145

Deci, E. L., \& Ryan, R. M. (1985). Intrinsic motivation and self-determination in human behavior. New York: Plenum. ISBN 978-1-4899-2271-7.

Dickinson, D. K., \& Snow, C. E. (1987). Interrelationships among prereading and oral language skills in kindergartners from two social classes. Early Childhood Research Quality, 2, 1-25.

Dickinson, D. K. (2002). Shifting images of developmentally appropriate practice as seen through different lenses. Educational Researcher, January/February, 26-32. Retrieved from http://www.jstor.org/stable/3594306

Donitsa-Schmidt, S., Inbar, O., \& Shohamy, E. (2004). The effects of teaching spoken Arabic on students' attitudes and motivation in Israel. The Modern Language Journal, 88, 217-228. https://doi.org/10.1111/j.00267902.2004.00226.x

Dörnyei, Z. (1990). Conceptualizing motivation in foreign-language learning. Language Learning, 40, 45-78. https://doi.org/10.1111/j.1467-1770.1990.tb00954.x

Dörnyei, Z. (2003). Attitudes, orientation, and motivations in language learning: advances in theory, research, and applications. Language Learning, 53, 3-32. https://doi.org/10.1111/1467-9922.53222

Dörnyei, Z. (2005). The psychology of the language learner. Mahwah, NJ: Erlbaum. ISBN 0-8058-4729-4

Dörnyei, Z. (2008). Second Language Motivation. Unpublished Research Interview. School of English, The University of Nottingham, UK.

Ehri, L. C., Nunes, S. R., Willows, D. M., Yaghoub-Zadeh, Z., \& Shanahan, T. (2001). Phonemic awareness instruction helps children learn to read: Evidence from the National Reading Panel's meta-analysis. Reading Research Quarterly, 36, 250-287. https://doi.org/10.1598/RRQ.36.3.2

Ehri, L. C., Nunes, S. R., Willows, D. M., Schuster, B. V., Yaghoub-Zadeh, Z., \& Shanahan, T. (2001). Phonemic awareness instruction helps children learn to read: Evidence from the National Gardner, R. C. (1985). Social psychology and second language learning: The role of attitudes and motivation. London: Arnold.

Gardner, R. C., \& Lambert, W. E. (1972). Attitudes and motivation in second language learning. Rowley, MA: Newbury House.

Gardner, R. C., Masgoret, A. M., \& Tremblay, P. F. (1999). Home background characteristics and second language learning. Journal of Language and Social Psychology, 18, 419-437. https://doi.org/10.1177/0261927X99018004004

Gottardo, A., \& Mueller, J. (2009). Are First- and Second-Language Factors Related in Predicting SecondLanguage Reading Comprehension? A Study of Spanish- Speaking Children Acquiring English as a Second Language from First to Second Grade. Journal of Educational Psychology 101, 2, 330-344. https://doi.org/10.1037/a0014320

McCormick, C. E., \& Mason, J. M. (1986). Intervention procedures for increasing preschool children's interest in and knowledge about reading. InW. H. Teale \& E. Sulzby (Eds.), Emergent literacy: Writing and reading (pp. 90-115). Norwood, NJ: Ablex. 
Näslund, J. C., \& Schneider, W. (1996). Kindergarten letter knowledge, phonological skills and memory processes: Relative effects on early literacy. Journal of Experimental Child Psychology, 62, 30-59. https://doi.org/10.1006/jecp.1996.0021

Pavlenko, A. (2003). 'Language of the enemy': foreign language education and national identity. Language Policy, 6, 313-331. https://doi.org/10.1080/13670050308667789

Ryan, R. M., \& Deci, E. L. (2000). Self-determination theory and the facilitation of intrinsic motivation, social development, and well-being. American Psychologist, 55, 68-78. https://doi.org/10.1037/0003-066X.55.1.68

Rogoff, B. (1990). Apprenticeship in thinking: Cognitive development in social context. Oxford University Press.

Scarborough, H. S. (1998). Early identifications of children at risk for reading disabilities: Phonemic awareness and some other predictors. In B. K. Shapiro, P. J. Accardo, \& A. J. Capute (Eds.), Specific reading disability: A view of the spectrum (pp. 75- 119). Timonium, MD: York Press.

Scarborough, H. (2002). Connecting early language and literacy to later reading (dis)abilities. In S. B. Neuman \& D. K. Dickinson (Eds.), Handbook of early literacy development (pp. 97-110). New York: Guilford.

Shatil, E. (2001). Haver Hadash [A new friend]. Kiryat Bialeek, Israel: Aha Books Press. Shatil, E., Share, D., \& Levin, I. (2000). On the contribution of kindergarten writing to grade 1 literacy: A longitudinal study in Hebrew. Applied Psycholinguistics, 21, 1-21.

Schumann, J. H. (1978). The acculturation model for second language acquisition. In R. C. Gingras (Ed.), Second language acquisition and foreign language teaching (pp. 27-50). Washington, DC: Center for Applied Linguistics.

Teale, W. H., \& Sulzby, E. (1986). Emergent Literacy as a Perspective for Examining How Young Children Become Writers and Readers. Norwood, NJ: Ablex. https://doi.org/10.12691/education-5-8-4

Wells, G. (1985). Pre-school related activities and success in school. In D. Olson, N. Torrance, \& A. Hildyard (Eds.), Literacy language and learning: The nature and consequences of reading and writing (pp. 229-255). Cambridge: Cambridge University Press. https://doi.org/10.1177/027112149401400405

Wells, G. (1985). Pre-school related activities and success in school. In D. Olson, N. Torrance, \& A. Hildyard (Eds.), Literacy language and learning: The nature and consequences of reading and writing (pp. 229-255). Cambridge: Cambridge University Press.

Whitehurst, G. J., \& Lonigan, C. J. (2002). Emergent literacy: Development from prereaders to readers. In S. B. Neuman \& D. K. Dickinson (Eds.), Handbook of early literacy development (pp. 11-29). New York: Guilford.

Yashima, T., Zenuk-Nishide, L., \& Shimizu, K. (2004). The influence of attitudes and affect on willingness to communicate and second language communication. Language Learning, 54, 119-152. https://doi.org/10.1111/j.1467-9922.2004.00250.x

\section{Appendix 1: Plurilingual School Play (Transcript)}

Characters: a British Speaker (Tourist), a French Speaker (Tourist) and a Portuguese Speaker (Waiter)

British speaker: Hello! Good morning!

Waiter: Hello! Hello! Mais um que chegou! (Another one has arrived!)

Mais um que chegou (in Portuguese the sound of 'hello' rhymes with 'chegou')

British speaker: This place is nice, landscape, hot weather...

Waiter: Yes, yes, nice, nice...

British speaker: Look, how can I go to the beach?

Waiter: Bicha? Aqui não há bicha! (Gay? There is no gay person here!)

Espere um pouquinho que eu atendo-o já...(pretends to clean the table) (Wait a moment and I'll be right here)

British speaker: No, no, to the sea, to the sea...

Waiter: Quer que eu vá aí? OK, be patient,just one moment...

British speaker: No, you didn't understand! 
Waiter: Bem, bem! Vamos lá a ver se nos entendemos: O senhor quer comer (makes body gesture to pretend to be eating) ou quer is comprar um automóvel ao stand?

British speaker: Oh my God, oh my God...! (Makes a gesture of waiting and returns with two bottles of water)

British speaker: Oh my God.

French speaker: Oh, mon Dieu! Oh, mon Dieu!!

Waiter: Bigode? Eu nem sequer tenho bigode!! (a French tourist comes by)

British speaker: Help me, please!

French speaker: Bonjous ça va...

Waiter: Vá, vá eleve também este que eu não entendo nada do que ele está para aqui a dizer...

French speaker: Oui, oui, c'est la vie...

Waiter: Se eu vi? Eu não vi ninguém...Digam mas é o que querem que eu tenho mais os que fazer...

French speaker: La plage, les oiseaux, les bateaux, et l'eau, comprend? L'eau, l'eau (makes gesture of swimming and drinking)

Waiter: Ah! Querem beber?! Pois está tanto calor! Já percebi o que querem...Já volto... (makes gesture of waiting and returns with two bottles of water)

The foreign speakers cross their arms, look at each other, nod their heads and say at the same time:

British speaker: Oh my God!!!

French speaker: Oh, mon Diew! Oh, mon Dieu!

THE END

\section{Appendix 2: Interview consent form Consent Form}

I agree to participate in a study of Second/ Foreign Language Pedagogy to young speakers of other languages (Portuguese), conducted by Carmen Lucas (a Ph.D. Candidate in Second/ Foreign language Pedagogy and Curriculum Development for learners in kindergarten and in Primary school ("Didáctica e Desenvolvimento Curricular") from University of Aveiro, Aveiro, Portugal, and a visiting scholar here in the University of Nottingham, School of Education) with the understanding that:

(1) The purpose of the study is to observe and develop an in-depth understanding of a scholars' expertise view;

(2) The interview will be audio-recorded by Carmen Lucas in the scholar's office for about an hour and a half. After this recording session, there will be data transcription and content analysis leading to emergent theory in the context of grounded theory;

(3) A research diary will be kept along the research study and it will be researcher's possession;

(4) The recording will be listened and analyzed by Carmen Lucas, and a limited number of associates, and only for educational and scientific research purposes. At all times the scholar's identity will be kept confidential;

(5) Conversely, I also recognize the participant's rights to be identified with any publication of his/her work or other inputs, if so he/she wishes;

a. I do wish to be identified with my own publications/work.

b. I do not wish to be identified with my own publications/work.

\section{Copyrights}

Copyright for this article is retained by the author(s), with first publication rights granted to the journal.

This is an open-access article distributed under the terms and conditions of the Creative Commons Attribution license (http://creativecommons.org/licenses/by/4.0/). 